ORIGINAL ARTICLE

\title{
LPA signaling initiates schizophrenia-like brain and behavioral changes in a mouse model of prenatal brain hemorrhage
}

\author{
H Mirendil ${ }^{1}$, EA Thomas ${ }^{1}, \mathrm{C}$ De Loera ${ }^{1}, \mathrm{~K} \mathrm{Okada}^{2}, \mathrm{Y}$ Inomata $^{3}$ and J Chun ${ }^{1}$
}

\begin{abstract}
Genetic, environmental and neurodevelopmental factors are thought to underlie the onset of neuropsychiatric disorders such as schizophrenia. How these risk factors collectively contribute to pathology is unclear. Here, we present a mouse model of prenatal intracerebral hemorrhage-an identified risk factor for schizophrenia-using a serum-exposure paradigm. This model exhibits behavioral, neurochemical and schizophrenia-related gene expression alterations in adult females. Behavioral alterations in amphetamine-induced locomotion, prepulse inhibition, thigmotaxis and social interaction-in addition to increases in tyrosine hydroxylase-positive dopaminergic cells in the substantia nigra and ventral tegmental area and decreases in parvalbumin-positive cells in the prefrontal cortex-were induced upon prenatal serum exposure. Lysophosphatidic acid (LPA), a lipid component of serum, was identified as a key molecular initiator of schizophrenia-like sequelae induced by serum. Prenatal exposure to LPA alone phenocopied many of the schizophrenia-like alterations seen in the serum model, whereas pretreatment with an antagonist against the LPA receptor subtype $\mathrm{LPA}_{1}$ prevented many of the behavioral and neurochemical alterations. In addition, both prenatal serum and LPA exposure altered the expression of many genes and pathways related to schizophrenia, including the expression of Grin $2 \mathrm{~b}$, SIc17a7 and Grid1. These findings demonstrate that aberrant LPA receptor signaling associated with fetal brain hemorrhage may contribute to the development of some neuropsychiatric disorders.
\end{abstract}

Translational Psychiatry (2015) 5, e541; doi:10.1038/tp.2015.33; published online 7 April 2015

\section{INTRODUCTION}

Schizophrenia is a complex neuropsychiatric disorder with $\sim 0.5 \%$ prevalence in the general population. ${ }^{1}$ There is a growing body of literature to support a significant link between obstetric complications and risk for psychiatric disorders. These environmental risk factors include diabetes, Rhesus incompatibility, bleeding, preeclampsia, premature rupture of membranes and preterm birth. ${ }^{2-7}$ Prenatal brain bleeding/hemorrhage during pregnancy, reported generally as 'cerebral trauma,' was, in fact one of the first environmental risk factors identified for schizophrenia., ${ }^{8,9}$ There are currently no animal models of fetal brain hemorrhage related to schizophrenia, but there are models that utilize maternal infection. These maternal infection models exhibit several neurochemical and behavioral alterations relevant to schizophrenia, ${ }^{10}$ and immunostimulatory agents such as interleukin- 6 and tumor necrosis factor alpha/beta have been implicated in these models.

A small lipid signaling molecule, lysophosphatidic acid (LPA), is known to be involved in immune activation and hemorrhage. ${ }^{11-13}$ Recently, a prenatal hemorrhage model using intraventricular injections of serum into mouse embryos was developed to study post-hemorrhagic hydrocephalus. ${ }^{14}$ In this model, a single, intraventricular injection of blood serum or high concentrations of LPA at embryonic day 13.5 (E13.5) was sufficient to induce severe and persistent hydrocephalus, characterized by ventriculomegaly, cortical mitotic displacement, ventricular-associated cadherin disruptions and cortical histological abnormalities such as neurorosettes and third ventricle occlusions. Most importantly, an LPA receptor antagonist was able to prevent all of these hydrocephalus characteristics when injected before LPA.

Prenatal hemorrhage, as well as infection, hypoxia and malnutrition, are epidemiologically linked to a variety of neurodevelopmental disorders that include hydrocephalus and schizophrenia. ${ }^{6}$ This linkage suggested that a spectrum of central nervous system effects might be initiated by common factors, whereby fetal hydrocephalus, with its alterations in brain morphology and severe ventriculomegaly, could represent one extreme outcome of prenatal hemorrhage. Conversely, a 'hypomorphic' outcome, which would not induce gross hydrocephalus but still affect the developing brain, might be produced by a milder insult. The identification of LPA as an initiating factor in fetal hydrocephalus suggested broader participation in other neurodevelopmental disorders.

As LPA is involved in both hemorrhagic events and immune activation, ${ }^{11-13}$ this suggested the potential involvement of LPA signaling in prenatal environmental insults. LPA acts through at least six currently identified cell surface $G$ protein-coupled receptors, $\mathrm{LPA}_{1}-\mathrm{LPA}_{6} .{ }^{15}$ These receptors are widely expressed in the developing brain, and LPA signaling affects a range of important neurodevelopmental processes, including cell proliferation, migration, process outgrowth and apoptosis. ${ }^{16}$ LPA is present in the blood and can reach concentrations in serum of up to $20 \mu \mathrm{m}^{17}$ which is on the order of 20000 -fold over apparent LPA receptor $\mathrm{K}_{\mathrm{D}} \mathrm{S} .{ }^{16} \mathrm{LPA}$ can also induce production of interleukin-6, tumor necrosis factor alpha/beta and other cytokines during immune activation or prenatal cerebral bleeding, ${ }^{18,19}$ providing a

\footnotetext{
Department of Molecular and Cellular Neuroscience, Dorris Neuroscience Center, The Scripps Research Institute, La Jolla, CA, USA; ${ }^{2}$ Advanced Medical Research Laboratories, Research Division, Mitsubishi Tanabe Pharma Corporation, Toda-shi, Saitama, Japan and ${ }^{3}$ Pharmacology Research Laboratories I, Research Division, Mitsubishi Tanabe Pharma Corporation, Yokohama, Japan. Correspondence: Dr J Chun, Department of Molecular and Cellular Neuroscience, Dorris Neuroscience Center, The Scripps Research Institute, 10550 North Torrey Pines Road, DNC-118, La Jolla, CA 92037, USA.

E-mail: jchun@scripps.edu
}

Received 17 September 2014; revised 15 January 2015; accepted 9 February 2015 
link between LPA signaling and previously identified prenatal environmental risk factors relevant to schizophrenia.

These observations led us to test the hypothesis that aberrant LPA receptor signaling during development could initiate schizophrenia-like deficits and represent a mechanism shared among environmental risk factors. Here we report the development of an embryonic environmental model of bleeding in the brain, which implicates aberrant LPA signaling as an environmental initiator of neurodevelopmental psychiatric disorders, particularly schizophrenia.

\section{MATERIALS AND METHODS}

\section{Prenatal injections}

All animal protocols were approved by the Institutional Animal Care and Use Committee at The Scripps Research Institute and conform to National Institutes of Health guidelines. Serum was isolated via cardiac puncture from adult female $\mathrm{C} 57 \mathrm{BL} / 6 \mathrm{~J}$ mice euthanized by $\mathrm{CO}_{2}$. Serum was allowed to clot at room temperature for $1 \mathrm{~h}$, spun down, diluted 1:4 with HBSS or $0.9 \%$ saline and frozen until use. LPA $(18: 1 ; 500 \mu \mathrm{m}$ in HBSS or $0.9 \%$ saline; Avanti Polar Lipids, Alabaster, AL, USA) was prepared just before use. All solutions had trace amounts of blue food-coloring dye.

In utero intraventricular injections were performed as previously described. ${ }^{14}$ Briefly, timed-pregnant C57BL/6J dams were mated in-house and anesthetized with $10 \mathrm{mg} \mathrm{kg}^{-1}$ nembutal on E13.5. Uterine horns were exposed through laparotomy and were kept moist throughout the surgery. A total $3 \mu \mathrm{l}$ vehicle (HBSS or $0.9 \%$ saline), serum or LPA were slowly injected into the left lateral ventricle of each embryo. Every embryo in each pregnant dam was injected with the same treatment. The uterine horns were replaced into the dam and the incision was sutured closed. Dams regained full body control and movement within $2 \mathrm{~h}$ of being anesthetized. Most dams delivered normally, and there was no variation in survival between treatment groups. Pharmacological studies using Ki16425 (Kirin Brewing/DebioPharm Group, Lausanne, Switzerland) were performed

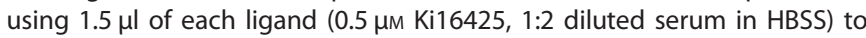
maintain consistent injection volumes.

\section{Behavior testing}

At 8 weeks of age, injected mice (2-5 per cage) were transferred to a reverse light-cycle box (0700-1900 h dark, 1900-0700 h light). After 2 weeks of acclimation, mice began behavior tests. Behavior tests were run sequentially between the hours of 0900 and 1700, with at least 1 day separating tests. The order of testing was as follows: prepulse inhibition (PPI), marble burying or stereotypy (data not shown), olfaction, light/dark, elevated plus maze, novel-object recognition, social interaction and open field. All the mice completed behavior tests in the same order and timeframe, except for a separate group that only underwent PPI testing, and no animals were deliberately excluded from analyses. Male and female mice from multiple litters per group were tested. All behavioral tests were videotaped (except PPI and open-field tests). All behavior tests were analyzed with two-way multivariate analysis of variance followed by Dunnet's post hoc correction for multiple comparisons (treatment and sex). See Supplementary Methods for full behavioral protocols.

\section{Receptor internalization assay}

$\mathrm{LPA}_{1}$-EGFP-B103 cells, which are rat B103 neuroblastoma cells with stable integration of an $\mathrm{LPA}_{1}$-EGFP construct, were grown overnight on poly- $\mathrm{L}$ lysine-coated $12-\mathrm{mm}$ glass coverslips. The following night, cells were switched to serum-free medium for $16-24 \mathrm{~h}$. The next day, cells were incubated with $10 \mathrm{~nm}, 1 \mu \mathrm{m}$ and $10 \mu \mathrm{m}$ concentrations of LPA (1-oleoyl-2hydroxy-sn-glycero-3-phosphate; Avanti Polar Lipids, Alabaster, AL, USA) for 5 or $30 \mathrm{~min}$ and then fixed with $4 \%$ paraformaldehyde/phosphatebuffered saline (PBS). Fixed cells were permeabilized in $0.1 \%$ Triton X-100/ PBS for $15 \mathrm{~min}$. F-actin was visualized by staining with $25 \mu \mathrm{g} \mathrm{ml}^{-1}$ rhodamine-phalloidin (Sigma) in PBS/1\% bovine serum albumin (BSA) for $30 \mathrm{~min}$. Images were acquired using a Nikon N-SIM (structured illumination microscopy) super-resolution microscope with an Andor iXon3 back-illuminated high sensitivity EMCCD camera with singlephoton detection capability (Nikon, Tokyo, Japan). Projections were rendered using 3D-SIM Elements software from Nikon.

\section{$\mathrm{Ca}^{2+}$ imaging}

Calcium signaling in LPA $_{1}$-EGFP-B103 cells were assessed as previously described. ${ }^{20}$ Briefly, serum-starved cells were loaded with fura-2 AM $(2 \mu \mathrm{M})$ in the presence of $1.5 \mu \mathrm{m}$ pluronic acid F-127 and incubated for 30-45 min at $37^{\circ}$ in the dark in Opti-MEM (Life Technologies, Carlsbad, CA, USA) buffer containing $2 \mathrm{~mm} \mathrm{CaCl}_{2}$ and either $0.1 \%$ BSA or $10 \mathrm{~nm}, 1 \mu \mathrm{m}$ or $10 \mu \mathrm{M}$ LPA. After $30 \mathrm{~min}$, the coverslips were washed $1 \times$ with Opti-MEM and secured to the bottom of a laminar flow perfusion chamber RC-25 (Warner Instruments, Hamden, CT, USA) with vacuum grease. Buffer (HBSS containing $20 \mathrm{~mm}$ HEPES pH4, $2 \mathrm{~mm} \mathrm{MgCl} 2,2 \mathrm{~mm} \mathrm{CaCl}$ ) was gently added and the chamber mounted on an Axiovert $200 \mathrm{M}$ microscope. Clearly distinguishable individual cells with bright GFP signals were chosen for imaging. Cells were constantly perfused at room temperature. Fresh $0.1 \%$ BSA and $1 \mu \mathrm{M}$ LPA-, and ionomycin-containing solutions were prepared immediately before use. The solutions were perfused through the chamber in the following order: $120 \mathrm{~s} \mathrm{BSA}, 60 \mathrm{~s} \mathrm{LPA}, 120 \mathrm{~s} \mathrm{BSA}, 60 \mathrm{~s}$ ionomycin. A change in intracellular calcium level was scored as a response of $50 \%$ over baseline levels. Only cells responding to ionomycin were included in total cell number assessment. Population data were compared using a Student's paired $t$-test.

\section{Immunohistochemistry}

Adult brains from C57BL/6J male and female prenatally injected mice were collected at least 2 weeks after the last behavioral test was performed, fixed in formalin-alcohol-acetic acid solution, paraffinized and sectioned coronally (8 um). Sections $24 \mu \mathrm{m}$ apart were used for immunohistochemistry analysis. Sections were processed through antigen retrieval (boiled for $10 \mathrm{~min}$ in $10 \mathrm{~mm}$ sodium citrate buffer), blocked with species-appropriate serum and the following antibodies were used: tyrosine hydroxylase (Millipore, Temecula, CA, USA, rabbit 1:500), parvalbumin (Millipore, mouse, 1:500), DCX (Abcam, Cambridge, UK, rabbit, 1:1000), proliferating cell nuclear antigen (Oncogene, Cambridge, MA, USA, mouse 1:100), anti-rabbit Alexa 488 (Invitrogen, Carlsbad, CA, USA, 1:1000) and anti-mouse 568 (Invitrogen, 1:1000). For tyrosine hydroxylase (TH) analyses, the ventral tegmental area was designated as Bregma's area -3.0 to $-3.8 \mathrm{~mm}$ and up to seven sections were stained and counted. Only those three sections containing the most tyrosine hydroxylase-positive $(\mathrm{TH}+)$ cells within the defined substantia nigra/ventral tegmental area (Bregma's $-3.0 \mathrm{~mm}$ to $-3.3 \mathrm{~mm}$ ) were averaged for final assessment in each group to avoid bias. For parvalbumin (PV) analyses, PV+ cells from three sections from the prelimbic prefrontal cortex (PFC, Bregma's area 1.8-1.4 mm) were counted within a $2 \times 2 \mathrm{~mm}$ fixed frame area. For neurogenesis analyses, cells in the dentate gyrus (Bregma's area $-1.2 \mathrm{~mm}$ to $-1.64 \mathrm{~mm}$ ) were counted following unbiased stereological techniques. Statistical analyses were done using one- or two-way analyses of variance with Bonferroni's post hoc correction.

\section{Microarray analysis}

The brain specimens from 8-week-old prenatally exposed female mice were collected. Mice were deeply anesthetized with isofluorane, killed by decapitation and the brain was quickly isolated and placed into ice-cold PBS. The PFC (Bregma's area 2.5-1.3 mm) and ventral tegmental area (Bregma's area -3.0 to $-4.2 \mathrm{~mm}$ ) were isolated quickly from the brain via microdissection in sterile PBS using a standard dissection stereomicroscope. The specimens were placed into sterile tubes, flash-frozen with liquid $\mathrm{N}_{2}$, and stored at $-80^{\circ}$ until use. RNA was isolated from tissue using an RNeasy Lipid Tissue Kit (Qiagen, Venlo Limburg, The Netherlands) as per instructions and frozen at $-80^{\circ}$ until use. RNA was first reverse transcribed into complementary DNA, and the template cDNA was then converted to Cy3-labeled complementary RNA by in vitro transcription using Agilent's Low Input Quick Amp Labeling Kit, one-color (Agilent, Santa Clara, CA, USA). The resulting CRNA $(0.6 \mu \mathrm{g})$ was hybridized to an Agilent SurePrint G3 Mouse GE $8 \times 60 \mathrm{~K}$ Microarray (Agilent) as per manufacturer's instructions and scanned by an Agilent G2565CA DNA Microarray Scanner (Agilent). The functional relevance of microarray data generated from LPA and serum-treated animals was analyzed using Ingenuity Pathways Analysis (Ingenuity Systems, www.ingenuity.com). RT-PCR (PCR with reverse transcription) validation of select genes (see Supplementary Materials for primer sequences) was performed using a GoTaq RT-PCR kit (Promega, Madison, WI, USA) as per manufacturer's instructions and run on a RotorGene 3000 (Qiagen). 
Statistical analyses

All the data were analyzed using a two-tailed students $t$-test for comparing means or parametric, one- or two-way analyses of variance with Bonferroni's post hoc correction, or two-way multivariate analysis of variance followed by Dunnet's post hoc correction for multiple comparisons (treatment and sex). Significance was set at $P<0.05$ and all analyses were performed using the statistical software StatPlus (AnalystSoft, StatPlus:mac LE for the Mac OSX) or Prism (GraphPad). No data points were excluded as outliers. No statistical methods were used to predetermine sample sizes, but our sample sizes are similar to those reported in previous publications. ${ }^{14,21-24}$

\section{RESULTS}

Prenatal serum exposure induces schizophrenia-like behavioral deficits

Intraventricular delivery of vehicle, LPA or diluted serum was administered to mouse embryos on E13.5. A concentration of $25 \%$ serum in HBSS was empirically determined not to produce hydrocephalus; higher concentrations resulted in ventriculomegaly and hydrocephalus (Supplementary Figure 1). Following intraventricular delivery of vehicle, LPA or serum, pups were born and developed postnatally for 10 weeks (Supplementary Figure 2). Between postnatal weeks 10 and 12, cohorts of adult animals treated at E13.5 were subjected to a battery of behavioral tests designed to test for a range of cognitive and negative symptom deficits associated with a variety of neuropsychiatric disorders. These tests were PPI, olfactory sensitivity, stereotypy or marble burying (data not shown), light/dark, elevated plus maze, novel-object recognition, social interaction and open field. At postnatal week 14, animals were killed for tissue isolation to perform immunohistochemical and gene expression analyses.

Baseline locomotor activity was significantly decreased in serum- and LPA-exposed mice compared with the vehicleexposed group (treatment $F_{3,76}=23.42, P=<0.0001$ ) of both sexes (sex $F_{1,72}=2.407, P=0.1252 ;$ Figures $1 a$ and $b$, Supplementary Figure 3). Normally, treatment with amphetamine (AMPH), a stimulant that increases the neurotransmission of dopamine, induces mild hyperactivity in adult mice, which was observed in the vehicle cohort (Figures $1 \mathrm{a}$ and $\mathrm{b}$ ), and significantly affects locomotor activity in schizophrenia models. AMPH treatment did induce hyperactivity (treatment $F_{3,40}=5.728, P=0.0023$ ), but only in serum-exposed female mice (time $F_{1,40}=105.0$, $P<0.0001$; treatment $F_{3,40}=18.81, P<0.0001$ ), fully ameliorating the baseline hypoactivity observed before AMPH treatment, whereas AMPH treatment had no effect on LPA-exposed females (Figure 1a) or males of either group (Figure 1b). Female serumand LPA-exposed mice both displayed significantly decreased PPI at $100 \mathrm{~dB}$, whereas males were unaffected (sex $F_{1,101}=17.00$, $P<0.0001$, Figures $1 \mathrm{c}$ and e, Supplementary Figure 4). There was no significant change in startle response by either sex (Supplementary Figure 5). Female serum- and LPA-exposed mice also showed significant deficits in exploratory behavior-induced anxiety, as evidenced by a decreased amount of time spent in the center block compared with vehicle-exposed mice (treatment $F_{3,40}$ $=5.124, P=0.0043$; sex $F_{1,40}=7.204, P=0.0105$ ) during an openfield test (Figure $1 \mathrm{f}$ ) and only serum-exposed female mice exhibited social interaction deficits (treatment $F_{3,57}=6.831$, $P=0.0005$; sex $\left.F_{1,57}=0.0689, P=0.7939\right)$ compared with vehicleexposed mice (Figure 1g). The other behavioral tests did not reveal differences between vehicle and serum- or LPA-exposed mice (Supplementary Table 1).

Deficits in PPI, locomotion, anxiety and social interaction are common phenotypes of both genetic, ${ }^{25}$ and especially other environmental, ${ }^{26}$ animal models of schizophrenia, suggesting face validity for this serum-initiated environmental mouse model. These data also suggest that fetal brain exposure to exogenous
LPA, a known bioactive component of serum, can induce schizophrenia-related behavioral changes in adults and phenocopies several of the behavioral deficits seen in the serum model. In addition, sex-specific differences, similar to those observed here, are commonly reported in mouse schizophrenia models, ${ }^{23,24,27}$ and human symptoms and incidence rates of schizophrenia are known to vary between males and females. ${ }^{28}$

Schizophrenia-like behavioral deficits in the serum model are primarily $\mathrm{LPA}_{1}$ dependent

LPA has six known receptors, and one of these receptors, $\mathrm{LPA}_{1}$ (gene name Lpar1), is highly relevant to neurodevelopment. Lpar1 shows pronounced gene expression in the mouse E13.5 brain, ${ }^{29}$ and was previously linked to major changes produced by serum and LPA in the initiation of hydrocephalus. ${ }^{14}$ We assessed the contribution of the $\mathrm{LPA}_{1}$ receptor to our prenatal serum-exposure model using Ki16425, a short-acting, dual $\mathrm{LPA}_{1 / 3}$ receptor antagonist. ${ }^{30}$ Although the dual-target effects of Ki16425 for LPA 1 and $\mathrm{LPA}_{3}$ would normally be of concern, available genetic and tissue expression data have shown that $\mathrm{LPA}_{3}$ is not expressed during development. ${ }^{20,29}$ Ki16745 was intraventricularly injected $10 \mathrm{~min}$ before serum exposure at concentrations previously determined to block LPA's effects on hydrocephalus. ${ }^{14}$

Pretreatment with Ki16425 did not affect the hypoactivity induced by prenatal serum exposure, but did prevent the hyperactivity induced by AMPH treatment in serum-exposed females (Figure 2a). Pretreatment with Ki16425 also completely prevented the PPI deficits (Figures $2 \mathrm{~b}$ and c) and exploratory deficit-induced anxiety (Figure 2d). Ki16425 had no effect on social interaction deficits (Figure 2e), nor were other behavioral deficits induced by prenatal Ki16425 exposure (Supplementary Table 1). All statistics were done between the four groups (vehicle, LPA, serum, $\mathrm{Ki}+$ serum) and are the same as those reported in the above section. These data indicate that multiple behavioral deficits associated with prenatal serum exposure are LPA receptor dependent and primarily involve $\mathrm{LPA}_{1}$ in the developing female brain.

Pretreatment with Ki16425 enabled short-term antagonism of $\mathrm{LPA}_{1}$ during a critical developmental window. However, genetic deletion of $\mathrm{LPA}_{1}$ had previously been linked to schizophrenia-like behavioral and neurodevelopmental deficits, 31,32 and these reported behavioral deficits overlap with those seen in our prenatal serum and LPA exposure model, including increased anxiety, alterations in exploratory behavior and PPI deficits. ${ }^{32,33}$ These data seemed to be paradoxical, since both activation and constitutive deletion of $\mathrm{LPA}_{1}$ appeared to mediate similar schizophrenia-like end points. However, prior receptor signaling studies on lysophospholipid receptors suggested an explanation via functional antagonism.

High levels of LPA produce agonism followed by functional antagonism of $\mathrm{LPA}_{1}$

The signaling of another lysophospholipid could provide an explanation for the analogous effects of prenatal LPA receptor activation and constitutive deletion. A similar paradox was previously observed for the action of the sphingosine 1-phosphate receptor $1 \quad\left(\mathrm{~S}_{1} \mathrm{P}_{1}\right)$. An $\mathrm{S} 1 \mathrm{P}$ receptor agonist, fingolimod, was found to produce an initial agonism followed by prolonged functional antagonism with continued drug exposure. ${ }^{34-37}$ This raised the possibility that an excess of LPA might similarly result in initial super-activation followed by prolonged functional antagonism of LPA receptors, thereby explaining the similar effects seen through both genetic removal of LPA receptors and their apparent overactivation.

Normally, $\mathrm{LPA}_{1}$ is internalized via endocytosis followed by recycling back to the cell surface. To test whether LPA exposure approximating the concentrations used in this model could 
a

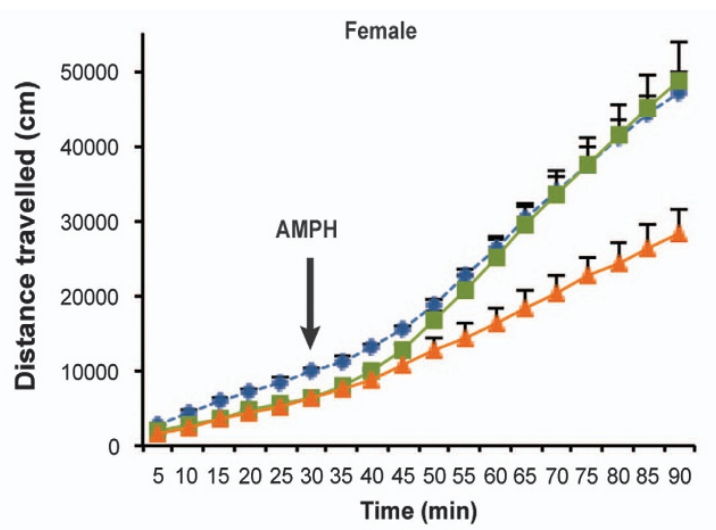

c

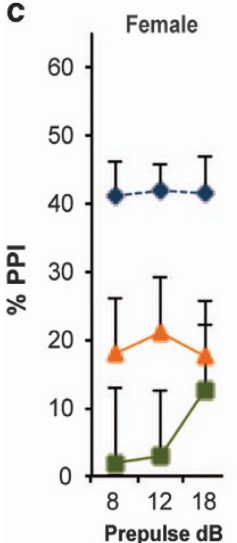

d

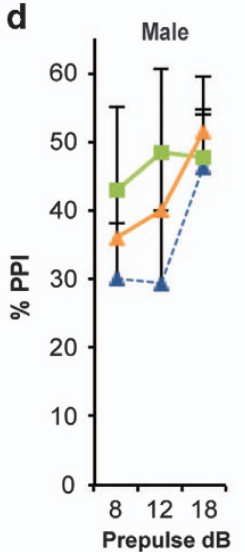

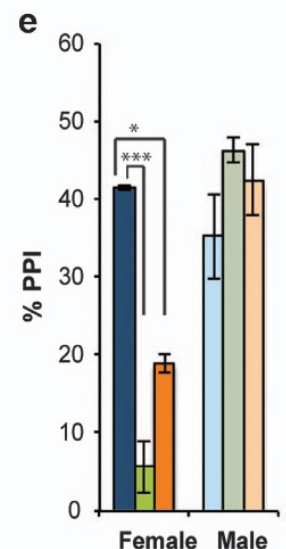
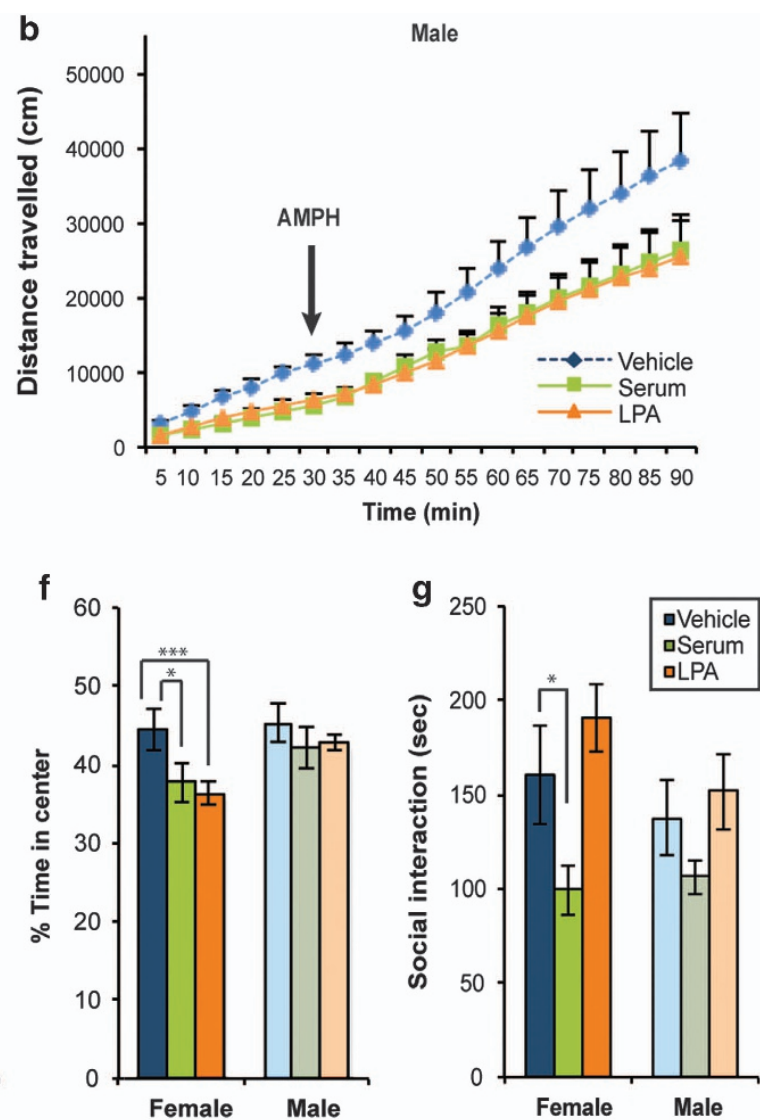

Figure 1. Prenatal serum and LPA exposure induces similar schizophrenia-like behavioral deficits in females. (a and b) Serum- and LPAexposed adult mice displayed hypoactivity during an initial 30-min period. Amphetamine (AMPH) treatment completely ameliorated the hypoactivity in serum-exposed female mice, but not LPA-exposed female or male mice of either group. (c-e) PPI was significantly decreased in female serum- and LPA-treated mice at $100 \mathrm{~dB}$ compared with controls. Three prepulse tones $(8,12$ and $18 \mathrm{~dB})$ were assessed. (f and $\mathbf{g})$ Female serum- and LPA-treated mice spent a decreased amount of time in the center of the open-field box over a 30-min period (f) and female serumexposed mice spent significantly less time interacting with a sex- and strain-matched stranger mouse (g). For each experiment, data were collected simultaneously for vehicle, serum, LPA and serum+Ki treatment group (see Figure 2, Supplementary Figure S1, Supplementary Figure S3 and Supplementary Figure S4). $n=7-17$ per sex and group, mean \pm s.e.m., ${ }^{*} P<0.05,{ }^{* *} P<0.001$. LPA, lysophosphatidic acid; NS, not significant; PPI, prepulse inhibition.

produce functional antagonism, $\mathrm{LPA}_{1}$-EGFP-B103 neuroblastoma cells were briefly pretreated with either BSA or increasing concentrations of LPA $(10 \mathrm{nM}-10 \mu \mathrm{M})$ and imaged using superresolution microscopy. Control (BSA) and lower concentrations of LPA allowed receptor recycling back to the cell surface (Figures 3a and d), whereas increasing concentrations of LPA induced prolonged receptor internalization (after ligand washout, Figures 3e and h). Following pretreatment with $10 \mu \mathrm{M}$ LPA, a loss of LPAactivated $\mathrm{Ca}^{2+}$ signaling was observed after subsequent challenge with $1 \mu \mathrm{M}$ LPA (30 min after initial exposure, Figures $3 \mathrm{i}$ and I). Therefore, increasing levels of LPA produced prolonged functional antagonism of $\mathrm{LPA}_{1}$ and resulted in a loss of $\mathrm{LPA}_{1}$ signaling (Figure $3 \mathrm{~m}$ ), which could in part explain the paradox of similar phenotypes seen in genetic LPA 1 nulls and the fetal hemorrhage/ LPA models involving high concentrations of exogenous LPA.

Prenatal serum or LPA exposure induces immunohistochemical changes in the adult brain that are partially dependent on LPA Within our prenatal mouse models, the number of dopaminergic cells was assessed using $\mathrm{TH}+$ immunoabeling in the midbrain of female animals exposed to prenatal serum, LPA or $\mathrm{LPA}_{1}$ antagonist (Ki16425+serum). Both prenatal serum- and LPA-exposed females displayed significantly increased numbers of $\mathrm{TH}+$ cells in the midbrain (treatment $F_{3,30}=14.35, P<0.0001$ ). Importantly, these changes in $\mathrm{TH}+$ cell number were completely prevented with
Ki16425 pretreatment (Figure 4a). The number of GABAergic, PV+ cells in the medial PFC of adult females was also assessed and, contrasting with dopaminergic cells, only prenatal serum-exposed mice displayed decreases in PV+ cells in the medial PFC (treatment $F_{3,25}=4.913, P=0.0078$ ), with no change seen in the LPA or Ki16425+serum models (Figure 4b).

Previous studies suggested a contribution of hippocampal neural stem cell proliferation to the pathophysiology of schizophrenia. $^{38}$ Yet, no evidence of altered hippocampal neurogenesis in either model (treatment $F_{2,29}=2.289, P=0.123$ ) was observed in proliferating (proliferating cell nuclear antigen) cells identified by the neural cell marker doublecorticin (DCX) in the hippocampus (Figure 4c).

Significant gene expression changes overlap between prenatal models and schizophrenia

Genome-wide transcriptome analyses were used to identify genes, pathways and networks associated with prenatal serum and LPA exposure models, as compared with genes linked to schizophrenia. The PFC and the midbrain (ventral tegmental area) of serum-, LPA- or vehicle-exposed female adult mice were compared, since females showed the most robust phenotypic changes. In total, there were between 1500 and 2100 differentially expressed messenger RNA gene transcripts $(P \leqslant 0.01)$ between female adult prenatal serum- or LPA-exposed brains versus vehicle-exposed 
a

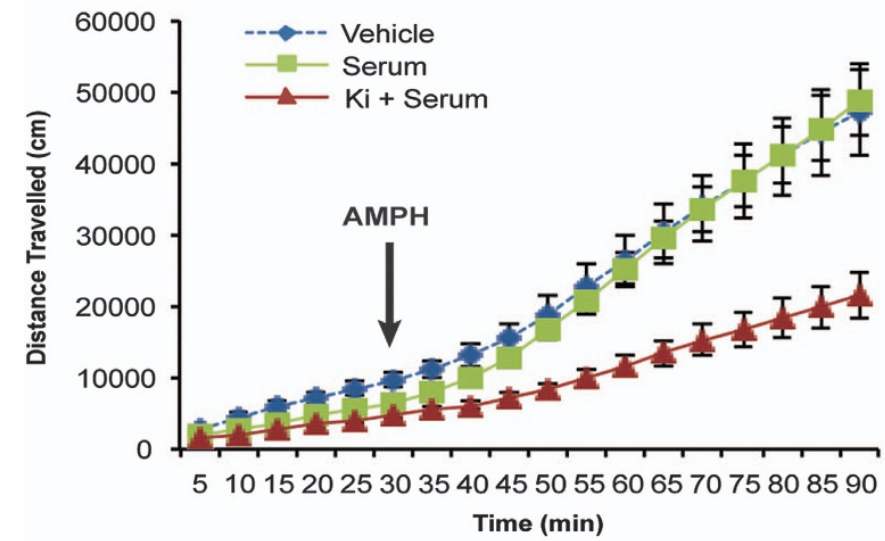

b

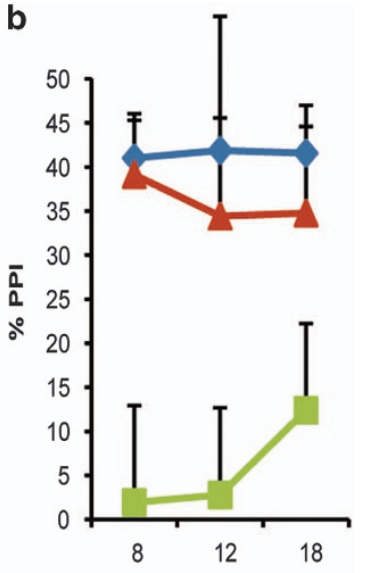

C

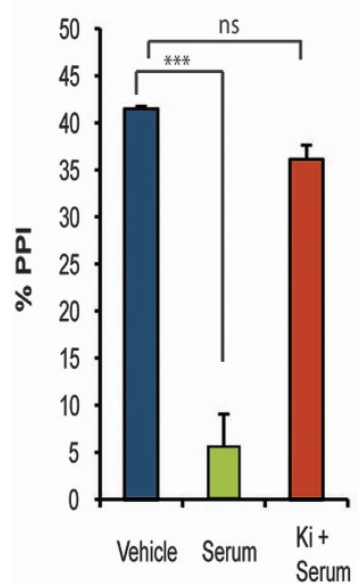

d

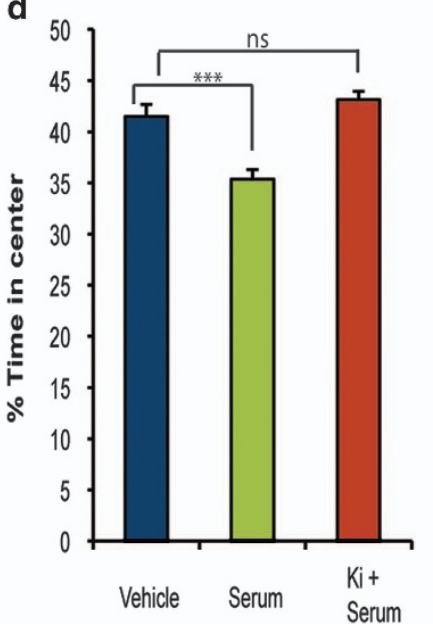

e

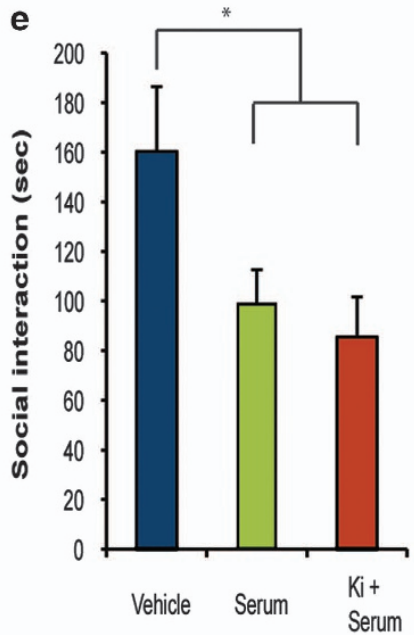

Figure 2. LPA $_{1}$ antagonism prevents serum-induced schizophrenia-like behavioral deficits in females. (a) LPA 1 antagonism through Ki16425 treatment did not prevent prenatal serum-induced decreases in locomotor activity, but did prevent AMPH-induced hyperlocomotion. (b and c) Treatment with Ki16425 prevented prenatal serum-induced deficits in PPI at $100 \mathrm{~dB}$. (d-e) Ki16425 treatment also prevented the decreased percentage of time female serum-exposed mice spent in the center of the open-field box over a 30-min period (d), but had no effect on serum-induced social interaction deficits (e). Data for vehicle and serum are as in Figure 1. All data were analyzed with multivariate two-way analysis of variance comparisons between groups (vehicle, serum, LPA and Ki16425+serum). $n=6-17$ per group, mean \pm s.e.m., ${ }^{*} P<0.05$, $* * * P<0.001$. LPA, lysophosphatidic acid; NS, not significant; PPI, prepulse inhibition.

control brains (PFC serum $=1815$, PFC $L P A=2129$, midbrain serum $=1828$ and midbrain LPA $=1467)$. There was $~ 50 \%$ overlap between the prenatal serum- and LPA-exposed groups, with most genes showing decreased expression compared with controls (Supplementary Figures 6a and b).

Pathway and network analyses were assessed with Ingenuity Pathways Analysis software, using only those genes concordantly dysregulated by both prenatal serum and LPA exposure (genes changed in the same direction and at a significance level of $P<0.05)$. Notably, alterations in several top canonical pathways relevant to schizophrenia-including calcium signaling, dopamine-DARPP32 feedback in CAMP signaling and synaptic long-term potentiation-were identified (Supplementary Tables $2 \mathrm{a}$ and $\mathrm{b}$ ). Several relevant networks of highly connected genes related to developmental disorders, gene expression, lipid metabolism and synaptic activity, among others, were also identified (Figure 5a, Supplementary Table 3). In particular, glutamatergic and GABAergic neurotransmitter pathways were affected by both prenatal serum and LPA exposure, emphasizing the global nature of neurotransmission-related alterations in our models.

Many genes previously implicated in the pathology of schizophrenia $^{39}$ were common to both models $(P<0.05$; Supplementary Table 4). In particular, 52 out of 278 genes previously identified in human genetic studies as strongly associated with schizophrenia ${ }^{40}$ were among the list of altered genes in both serum and LPA models, compared with only 13 of 278 genes selected at random from the entire list of genes present on the microarray. This number reflected a statistically significant overrepresentation of schizophrenia-associated genes concomitantly regulated by both serum and LPA exposure (Fisher's exact probability test, two-side probability threshold; $P<0.0001$ ).

Gene expression data were also compared with a list of the most reproduced, differentially expressed genes in human postmortem brain samples from schizophrenia patients. This list contained 679 distinct genes identified from a meta-analysis of 12 individual gene expression data sets involved in 988 arrays from the Stanley Medical Research Database. ${ }^{41}$ Serum exposure resulted in 127 of 679 (18.7\%) differentially expressed genes, while LPA exposure resulted in 143 of $679(21.1 \%)$, with an overlap between serum and LPA of 53 genes (Figure 5b, Supplementary Table 5). Quantitative PCR validation of selected genes verified the decreased expression of several glutamatergic-related genes (Figures $5 c$ and d). Collectively, these data indicate that prenatal serum or LPA exposure induces significant and overlapping alteration in gene expression, particularly in genes associated with neurotransmission. 
a

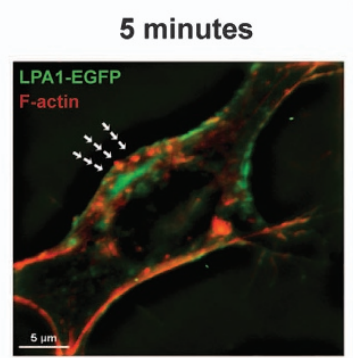

c

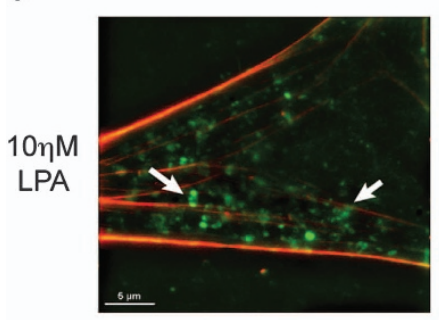

e

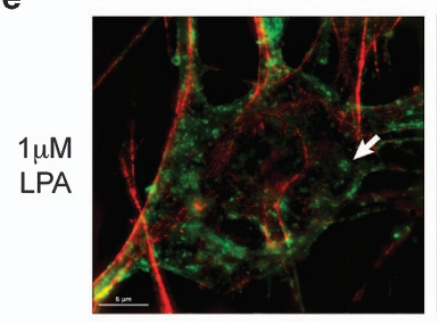

g

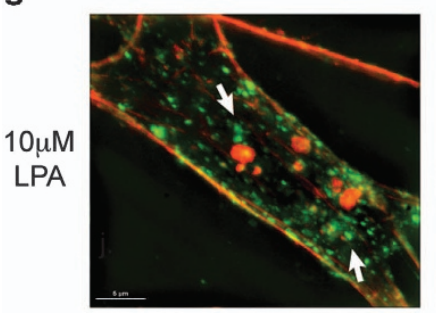

b $\quad 30$ minutes

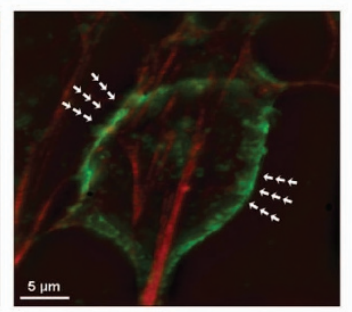

d

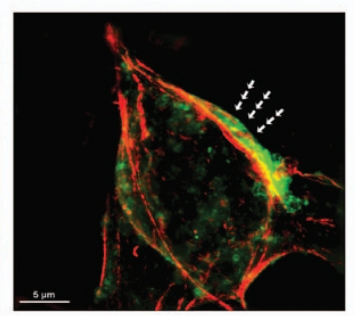

f

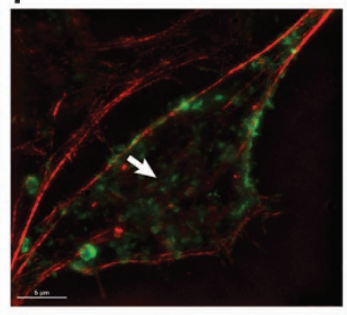

h

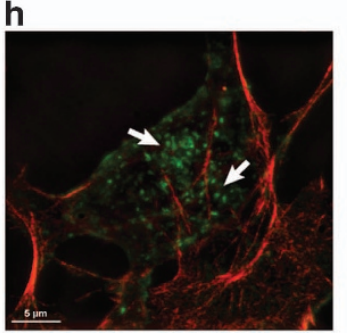

i

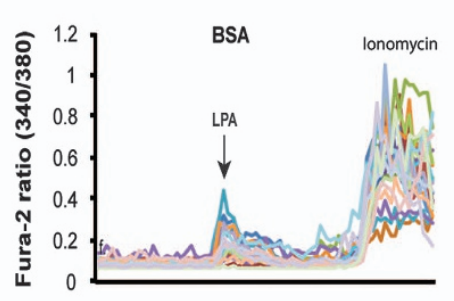

k

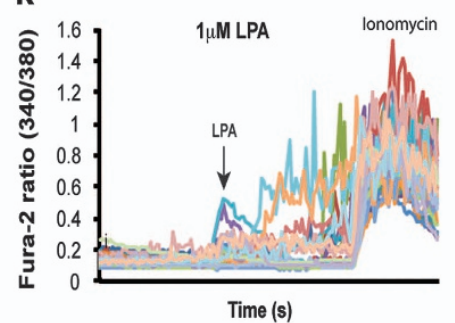

m

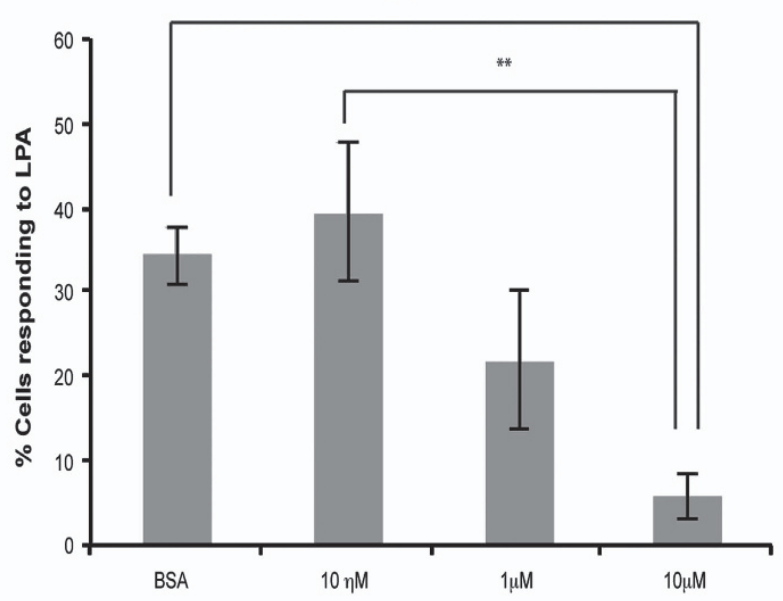

Figure 3. High levels of LPA produce initial agonism followed by functional antagonism of LPA 1 after LPA exposure. Receptor internalization was monitored in EGFP-LPA 1 -B103 neuroblastoma cells combined with fluorescence microscopy and functional calcium imaging. (a, c, e and g) Receptors localized on the cell surface (green signal, dashed arrowheads, a) are rapidly internalized with increasing LPA concentration (green vesicles, arrows, $\mathbf{c}$, e and $\mathbf{g}$ ). (b and d) After $30 \mathrm{~min}$, cells exposed to BSA and low concentrations of LPA (10 nM) exhibit LPA 1 receptor recycling that returns receptors to the cell surface (dashed arrowheads). ( $\mathbf{f}$ and $\mathbf{h}$ ) In contrast, exposure to high concentrations of LPA (1 and $10 \mu \mathrm{m})$ resulted in prolonged and sustained receptor internalization (arrows), effectively removing receptors from the cell surface. (i-m) To assess calcium signaling, cells were pretreated with BSA or increasing concentrations of LPA for 5 min, washed and after 30 min were challenged with $1 \mu \mathrm{m}$ LPA followed by assessment of cell signaling viability using ionomycin. Normal levels of LPA-stimulated intracellular Ca ${ }^{2+}$ (i and $\mathbf{j})$ contrasted with reduced ( $\mathbf{k}$ ) and absent (I) Ca2+ release in cells exposed to higher LPA pretreatment concentrations, indicating functional antagonism of the internalized receptors ( $m$, BSA $n=7,10 \mathrm{~nm}$ LPA $n=6,1 \mu \mathrm{m}$ LPA $n=5,10 \mu \mathrm{m}$ LPA $n=6$, mean \pm s.e.m.). Data were analyzed with Student's two-tailed $t$-test, ${ }^{* *} P<0.01,{ }^{* * *} P<0.0001$. BSA, bovine serum albumin; LPA, lysophosphatidic acid.

\section{DISCUSSION}

In this study, a new environmental model of prenatal brain hemorrhage was developed and found to display both face (Table 1) and construct validity (through modeling a validated schizophrenia risk factor) as a schizophrenia-like model for neuropsychiatric disease. ${ }^{42} \mathrm{LPA}_{1}$ receptor signaling was identified as a common molecular pathway initiated by prenatal serum exposure. In particular, overactivation with subsequent functional antagonism of $\mathrm{LPA}_{1}$ during prenatal hemorrhage appears to produce specific dopaminergic and glutamatergic signalingrelated behavioral deficits such as PPI, altered exploratory behavior-induced anxiety and sensitivity to dopaminergic signaling-induced behaviors.
As increases in LPA concentrations are present in many of the environmental risk factors associated with schizophrenia, such as infection, ${ }^{12}$ bleeding ${ }^{13}$ and hypoxia, ${ }^{43}$ LPA receptor overactivation followed by prolonged functional antagonism during neurodevelopment could represent a common link between different environmental risk factors. In addition to LPA, other factors present in serum include immune-related signaling molecules, such as interleukin-6, tumor necrosis factor alpha and interleukin-1 beta, which are elevated during bleeding, immune activation and other environmental insults. It is likely that one or more of these factors mediate non-LPA induced changes by serum, such as the observed social interaction deficits in the prenatal hemorrhage model. 

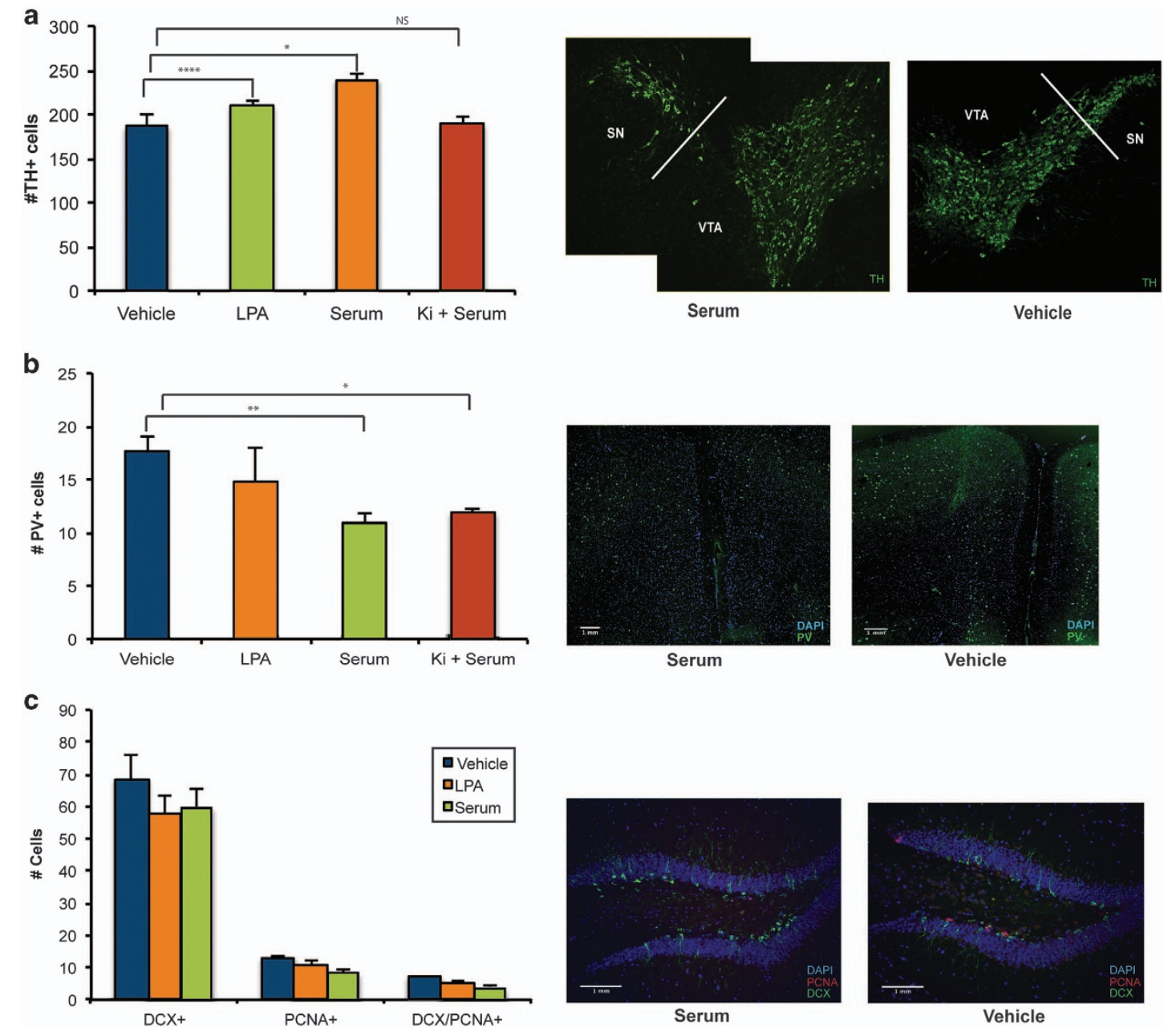

Figure 4. Prenatal serum exposure induces stereotypical dopaminergic and GABAergic immunohistochemical alterations partially dependent on LPA $_{1}$ signaling. (a) In adult female mice, serum and LPA exposure increased dopaminergic cell numbers in the midbrain (Bregma coordinates -3.00 to -3.80 ; tyrosine hydroxylase ( $\mathrm{TH}+$, green). Ki16425 treatment (Ki+serum) prevents TH+ cell number increases. (b) Serum exposure, but not LPA, reduces parvalbumin cell number (PV+, green) in the prelimbic medial prefrontal cortex (Bregma coordinates $1.80-$ 1.40) independent of $\mathrm{LPA}_{1}$ signaling. (c) Hippocampal neurogenesis (number of DCX+/PCNA+ cells) was not affected (Bregma coordinates -1.20 to -2.00 ). All data were analyzed with two-way multivariate analysis of variance comparisons between groups (vehicle, serum, LPA and Ki16425+serum when applicable). $n=4-7$ per group, mean \pm s.e.m. ${ }^{*} P<0.05,{ }^{* *} P<0.01,{ }^{* * * *} P<0.0001$. LPA, lysophosphatidic acid; NS, not significant; PCNA, proliferating cell nuclear antigen; VTA, ventral tegmental area.

Both the LPA and hemorrhage/serum models of both sexes display an interesting baseline hypoactivity. When these mice are exposed to amphetamine, male and female LPA-exposed and male serum-exposed mice are insensitive to amphetamine-induced hyperactivity. $\mathrm{LPA}_{1}$ receptor antagonism does not prevent this hypoactivity, suggesting the action of an additional LPA receptor. The amphetamine insensitivity may be a result of altered glutamatergic neurotransmission or even monoaminergic transmission, which has been shown in other rodent models of decreased amphetamine sensitivity. ${ }^{44,45}$ However, the serum-exposed females are significantly affected by amphetamine exposure. The baseline hypolocomotion serum-exposed females exhibit is not only treated upon amphetamine exposure, bringing the values up to those of vehicle-exposed female mice, but also induces prolonged hyperactivity in serum-exposed female mice (Supplementary Figures $3 \mathrm{c}$ and d). Importantly, this is an LPA-dependent hypersensitivity to amphetamine. $\mathrm{LPA}_{1}$ inhibition, therefore, appears to prevent amphetamine-induced hyperlocomotion in serum-exposed females, though does not affect the baseline hypoactivity.

There have been many previous reports on sex differences in the development of neuropsychiatric symptoms in both humans ${ }^{28}$ and mouse models. ${ }^{23,27}$ Disease onset and time course are different between male and female schizophrenia patients, ${ }^{28}$ and a recent study suggested that males and females have different molecular profiles, with females exhibiting dysregulation in inflammationrelated pathways. ${ }^{46}$ Estrogen is known to increase the immune response, whereas androgens decrease it. ${ }^{47}$ Consequently, females are known to display stronger antibody responses, increased resistance to foreign grafts and an increased risk for autoimmune diseases. ${ }^{48}$ Some maternal infection mouse models of schizophrenia (MIA models) also display sex-specific deficits, ${ }^{27}$ and LPA and hemorrhage events are known to induce immune activation. ${ }^{49}$

A recent report described sex-specific $\mathrm{S}_{1} \mathrm{P}_{2}$ expression increases in multiple sclerosis female patients and in a mouse model for multiple sclerosis. ${ }^{50}$ S1P is a bioactive lipid similar to LPA, and these data suggest the possibility that differential timing and location-specific expression of $\mathrm{LPA}_{1}$ in females during development could drive the sex-specific behavioral deficits seen in our models. In addition, one of the original reports on $\operatorname{Lpar}^{(--)}$mice described a female-specific PPI deficit, ${ }^{32}$ whereas subsequent reports using a modified $L$ par $1^{(-)}$line showed behavioral deficits in males (females were not tested). ${ }^{31,51-53}$ Further assessment of LPA receptor deletion in strain- and sex-specific populations will provide a greater understanding of potential behavioral modifier 
a

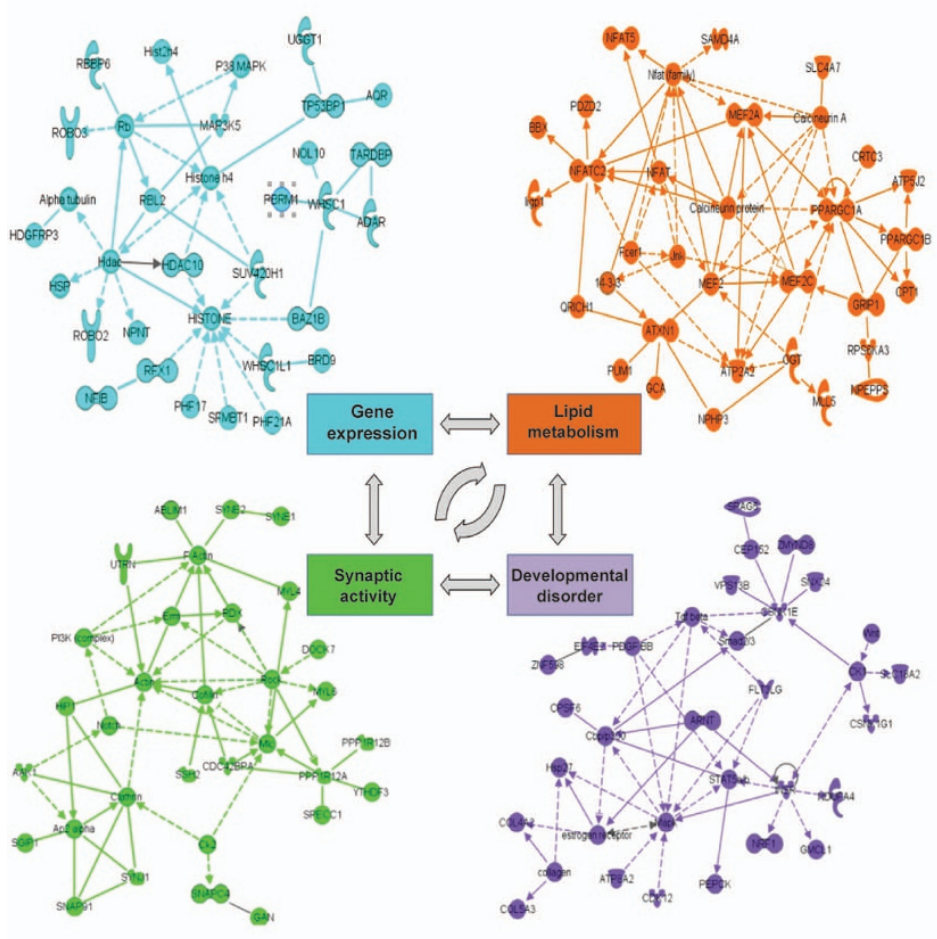

b
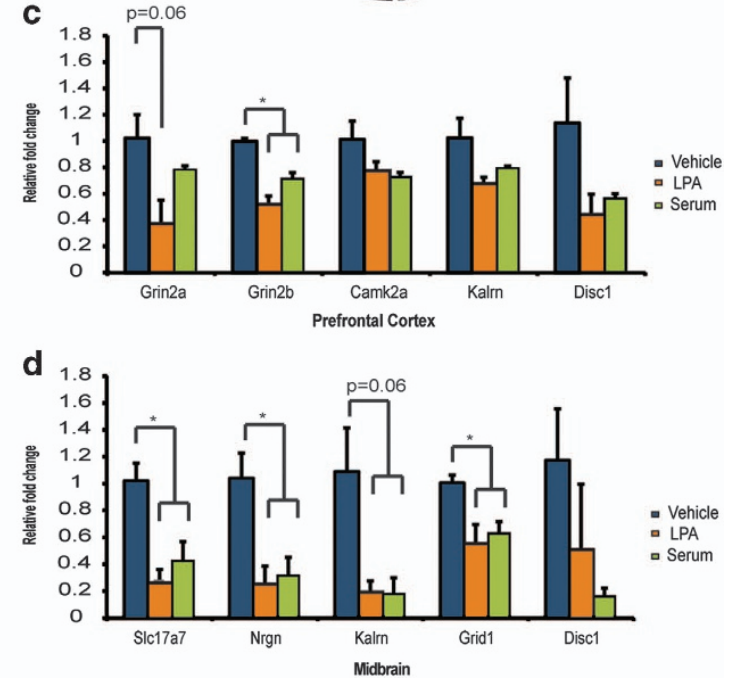

Figure 5. Prenatal serum- and LPA exposure alters gene expression profiles relevant to schizophrenia in adult animals. RNA was isolated from female adult prefrontal cortex (Bregma coordinates 2.50-1.30) and midbrain (Bregma coordinates -3.00 to -4.20 ) and gene expression changes were assessed by microarray analyses ( $n=5$ per group). (a) Gene networks of greatest relevance were related to developmental disorder, gene expression, lipid metabolism and synaptic activity in the prefrontal cortex (as determined by Ingenuity Pathway Analysis software). (b) Venn diagram illustrating overlap between genes altered with serum/LPA exposure and schizophrenia-related genes in the combined midbrain and prefrontal cortex. (c and d) RT-PCR (PCR with reverse transcription) validation of selected genes ( $n=3$, mean \pm s.e.m., Student's $t$-test, $\left.{ }^{*} P<0.05\right)$. LPA, lysophosphatidic acid.

Table 1. Summary of the effects that prenatal exposure to serum, LPA and $\mathrm{LPA}_{1}$ antagonist produced in adult female mice

\begin{tabular}{lccc}
\hline Schizophrenia-related deficits & Serum & LPA & LPA1 antagonist \\
\hline PPI & $\downarrow$ & $\downarrow$ & $\uparrow$ \\
Induced hyperactivity & $\uparrow$ & - & $\downarrow$ \\
Anxiety & $\uparrow$ & $\uparrow$ & $\downarrow$ \\
Social interaction & $\downarrow$ & - & - \\
Dopaminergic alterations & $\uparrow$ & $\uparrow$ & $\downarrow$ \\
GABAergic alterations & $\downarrow$ & $\pm^{\mathrm{a}}$ & $\overline{\mathrm{a}}^{\mathrm{a}}$ \\
Glutamatergic alterations & $\downarrow$ & $\downarrow$ & $\mathrm{NA}$ \\
\hline
\end{tabular}

Abbreviations: LPA, lysophosphatidic acid; NA, not assessed; PPI, prepulse inhibition; $\mathrm{PV}+$, parvalbumin-positive. Prenatal serum exposure induces several schizophrenia-related behavioral and neurochemical deficits that are primarily dependent on LPA receptor signaling. These models display good face validity (through validated schizophrenia-like deficits) and construct validity (through the modeling of prenatal hemorrhaging, a validated schizophrenia risk factor). ${ }^{\mathrm{a}} \mathrm{PV}+$ cell numbers were not decreased in prenatal LPA-exposed females. However, the expression of many GABAergic-related genes was altered in the PFC and midbrain of female mice prenatally exposed to LPA.

genes associated with LPA receptor signaling. Ultimately, our findings suggest that prenatal hemorrhage may impact females more severely than males, at least in the C57BL/6J background utilized here. It is also possible that differences in the timing and duration of prenatal insults are necessary to observe prenatal hemorrhage-induced schizophrenia symptoms in males. In addition, at least one LPA receptor $\left(\mathrm{LPA}_{4}\right)$ is X-linked, which may contribute to the sexual dimorphism observed here.

Receptor and timing mechanisms may also explain the effects of high concentrations of LPA that produce functional antagonism of $\mathrm{LPA}_{1}$. A relatively brief functional antagonism within a 'critical period $^{154}$ of susceptibility appears to be sufficient to produce a phenotypic change. Notably, functional antagonism is the mechanism used by a highly related agonist-receptor combination of S1P and one of its cognate receptors, $\mathrm{S}_{1} \mathrm{P}_{1}{ }^{36} \mathrm{~S} 1 \mathrm{P}$, like LPA, is a lysophospholipid, which also signals through related $G$ proteincoupled receptors (historically, $\mathrm{S}_{1} \mathrm{P}_{1}$ was first thought to be an LPA receptor). ${ }^{55}$ An S1P receptor modulator, fingolimod, ${ }^{56-58}$ was found to produce an initial agonism followed by prolonged functional antagonism with continued drug exposure. ${ }^{34-37}$ In fact, recovery of $\mathrm{S}_{1} \mathrm{P}_{1}$ expression required 2-8 days following an initial incubation with fingolimod. ${ }^{34}$ Therefore, the functional antagonism of $\mathrm{LPA}_{1}$ observed here by calcium imaging and receptor internalization, during a critical developmental window could account for the overlapping behavioral phenotype seen in the constitutive $\mathrm{LPA}_{1}$ receptor deletion mutant. Functional antagonism and the resultant influence on NPCs likely takes place during a comparatively brief critical period of susceptibility, however, many cells expressing LPA at that stage of development would likely be affected.

Disturbances in dopaminergic and glutamatergic neurotransmission, as well as deficits in GABAergic regulation, have frequently been observed in schizophrenia patients and models. ${ }^{59,60}$ Alterations in cell numbers-like the $\mathrm{TH}+$ dopaminergic cell increases seen not only in our prenatal hemorrhage model but also in $\mathrm{MIA}^{21}$ schizophrenia-like 
models - frequently portend disruptions in the balance between excitatory and inhibitory neurotransmission. ${ }^{59}$ Glutamatergic signaling alterations, both through NMDA and AMPA receptors, are particularly implicated in schizophrenia-like behavioral deficits, ${ }^{61}$ and LPA is known to initiate glutamate uptake. ${ }^{62}$ Modification of LPA expression has also been specifically linked to altered miniature excitatory postsynaptic potential kinetics and frequency, inhibitory postsynaptic potential amplitude and gamma oscillations. ${ }^{63-65}$ These data implicate LPA signaling-induced neurotransmission alterations as a possible mechanism for the specific glutamatergic and dopaminergic-related neural network and behavioral deficits manifested by our mouse model of prenatal hemorrhage. Future studies will characterize LPA's effect on neurotransmission within this model, particularly in relation to antipsychotic drug therapy and predictive validity for schizophrenia-related behaviors.

Schizophrenia is a disease dependent on synergistic interactions between multiple environmental, genetic and epigenetic risk factors. LPA has been linked to many of the underlying pathways involved in these risk factors. Glycogen synthase kinase 3 (Gsk3)a signaling network node affected by several schizophreniarelated risk factors such as Disc1, Nrg1, thymoma viral protooncogene 1 (Akt1) and reelin-can be regulated by $\mathrm{LPA}_{1}{ }^{66-69}$ Disturbances in neural precursor cell migration, proliferation and cortical layer formation are strongly linked to several environmental and genetic risk factors, and LPA receptor modulation is known to be capable of disrupting these neurodevelopmental processes. ${ }^{15}$ Alterations in LPA receptor signaling could represent a shared, proximal modulator of these molecular and cellular events; specifically those events initiated by hemorrhage or related environmental risk factors for schizophrenia. Notably, gene expression analyses identified a significant overlap with a highly validated schizophrenia-related gene set in both serumand, especially, LPA exposure models.

The relationship of our model to a more severe phenotype, hydrocephalus, is consistent with the heterogeneity seen in other schizophrenia models. Prenatal exposure to high concentrations of LPA (10 mm in $3 \mu \mathrm{l}$ ) during peak neurogenesis (E13.5) induces severe hydrocephalus and ventricular dilation, ${ }^{14}$ whereas low concentrations $(500 \mu \mathrm{m}$ in $3 \mu \mathrm{l})$ initiate schizophrenia-like deficits. A similar relationship is seen in the MIA model, which displays more severe, schizophrenia-like deficits when induced during early gestation (E9), but displays autism-like deficits when induced during late gestation (E16.5). ${ }^{70}$ The involvement of LPA signaling in neurological and neuropsychiatric diseases as diverse as hydrocephalus and schizophrenia suggests that a range of neurological effects could be initiated by aberrant LPA receptor signaling. Several other neurodevelopmental disorders, including cerebral palsy, ${ }^{71}$ bipolar disorder, ${ }^{72}$ depression ${ }^{73}$ and autism, ${ }^{74}$ have also been epidemiologically associated with prenatal bleeding. It is possible that the timing, severity and/or duration of aberrant LPA receptor signaling during prenatal bleeding could also contribute to the development of a number of these disorders. Considering the tractability of this receptor family for therapeutics, as demonstrated by the FDA's approval of fingolimod for the treatment of multiple sclerosis, ${ }^{58}$ targeting LPA receptors may offer a therapeutic approach to some forms of neurological and neuropsychiatric disease.

\section{CONFLICT OF INTEREST}

The authors declare no conflict of interest.

\section{ACKNOWLEDGMENTS}

We thank Dr Amanda Roberts (The Scripps Research Institute) for behavioral testing expertise and training, Dr Kathy Spencer (The Scripps Research Institute), Dr Ariana Lorenzana (Nikon) for microscopy imaging expertise and training, and Dr Yun Yung (The Scripps Research Institute) for in vivo surgery assistance. We thank Danielle
Jones and Dr Julian Wong for editorial assistance. This work was supported by NIH grants TL1 RR025772 (HM), R25 GM083275 (CD) and R01 MH051699, NS084398 and R56 NS082092 (JC).

\section{REFERENCES}

1 Saha S, Chant D, Welham J, McGrath J. A systematic review of the prevalence of schizophrenia. PLoS Med 2005; 2: e141.

2 Byrne M, Agerbo E, Bennedsen B, Eaton WW, Mortensen PB. Obstetric conditions and risk of first admission with schizophrenia: a Danish national register based study. Schizophr Res 2007; 97: 51-59.

3 Indredavik MS, Vik T, Evensen KA, Skranes J, Taraldsen G, Brubakk AM. Perinatal risk and psychiatric outcome in adolescents born preterm with very low birth weight or term small for gestational age. J Dev Behav Pediatr 2010; 31: 286-294.

4 Hamlyn J, Duhig M, McGrath J, Scott J. Modifiable risk factors for schizophrenia and autism--shared risk factors impacting on brain development. Neurobiol Dis 2013; 53: 3-9.

5 Cannon M, Jones PB, Murray RM. Obstetric complications and schizophrenia: historical and meta-analytic review. Am J Psychiatry 2002; 159: 1080-1092.

6 Hultman CM, Sparén P, Takei N, Murray RM, Cnattingius S. Prenatal and perinatal risk factors for schizophrenia, affective psychosis, and reactive psychosis of early onset: case-control study. BMJ 1999; 318: 421-426.

7 Boog G. Obstetrical complications and subsequent schizophrenia in adolescent and young adult offsprings: is there a relationship? Eur J Obstet Gynecol Reprod Biol 2004; 114: 130-136.

8 Rosanoff AJ, Handy LM, Plesset IR, Brush S. The etiology of so-called schizophrenic psychoses, with special reference to their occurrence in twins. Am J Psychiatry 1934; 91: 247-286.

9 Torrey EF, Hersh SP, McCabe KD. Early childhood psychosis and bleeding during pregnancy. A prospective study of gravid women and their offspring. $J$ Autism Child Schizophr 1975; 5: 287-297.

10 Meyer U. Prenatal Poly(l:C) exposure and other developmental immune activation models in rodent systems. Biol Psychiatry 2014; 75: 307-315.

11 Eichholtz T, Jalink K, Fahrenfort I, Moolenaar WH. The bioactive phospholipid lysophosphatidic acid is released from activated platelets. Biochem $J$ 1993; 291: 677-680.

12 Cummings R, Zhao Y, Jacoby D, Spannhake EW, Ohba M, Garcia JG et al. Protein kinase Cdelta mediates lysophosphatidic acid-induced NF-kB activation and interleukin-8 secretion in human bronchial epithelial cells. J Biol Chem 2004; 279: 41085-41094.

13 Li ZG, Yu ZC, Yu YP, Ju WP, Wang DZ, Zhan X et al. Lysophosphatidic acid level and the incidence of silent brain infarction in patients with nonvalvular atrial fibrillation. Int J Mol Sci 2010; 11: 3988-3998.

14 Yung YC, Mutoh T, Lin ME, Noguchi K, Rivera RR, Choi JW et al. Lysophosphatidic acid signaling may initiate fetal hydrocephalus. Sci Transl Med 2011; 3: 87-99.

15 Mirendil H Lin M-E Chun J. Lysophosphatidic acid (LPA) receptor signaling. Chun, J, Hla, T, Spiegel, S, Moolenaar, W (eds). Lysophospholipid Receptors: Signaling and Biochemistry. John Wiley \& Sons: Hoboken, NJ, USA, 2013. 1-39.

16 Choi JW, Herr DR, Noguchi K, Yung YC, Lee CW, Mutoh T et al. LPA receptors: subtypes and biological actions. Annu Rev Pharmacol Toxicol 2010; 50: 157-186.

17 Aoki J, Taira A, Takanezawa Y, Kishi Y, Hama K, Kishimoto T et al. Serum lysophosphatidic acid is produced through diverse phospholipase pathways. J Biol Chem 2002; 277: 48737-48744.

18 Xu MY, Porte J, Knox AJ, Weinreb PH, Maher TM, Violette SM et al. Lysophosphatidic acid induces alphavbeta6 integrin-mediated TGF-beta activation via the LPA2 receptor and the small G protein G alpha(q). Am J Pathol 2009; 174: 1264-1279.

19 Hao F, Tan M, Wu DD, Xu X, Cui MZ. LPA induces IL-6 secretion from aortic smooth muscle cells via an LPA1-regulated, PKC-dependent, and p38alpha-mediated pathway. Am J Physiol Heart Circ Physiol 2010; 298: H974-H983.

20 Dubin A. E, Herr D. R, Chun J. Diversity of lysophosphatidic acid receptormediated intracellular calcium signaling in early cortical neurogenesis. $J$ Neurosci 2010; 30: 7300-7309.

21 Vuillermot S, Weber L, Feldon J, Meyer U. A longitudinal examination of the neurodevelopmental impact of prenatal immune activation in mice reveals primary defects in dopaminergic development relevant to schizophrenia. J Neurosci 2010; 30: 1270-1287.

22 Smith SEP, Li J, Garbett K, Mirnics K, Patterson PH. Maternal immune activation alters fetal brain development through interleukin-6. J Neurosci 2007; 27: 10695-10702.

23 Kuroda K, Yamada S, Tanaka M, lizuka M, Yano H, Mori D et al. Behavioral alterations associated with targeted disruption of exons 2 and 3 of the Disc 1 gene in the mouse. Hum Mol Genet 2011; 20: 4666-4683.

24 Chesworth R, Downey L, Logge W, Killcross S, Karl T. Cognition in female transmembrane domain neuregulin 1 mutant mice. Behav Brain Res 2012; 226: 218-223. 
25 Desbonnet L, Waddington JL, O'Tuathaigh CMP. Mice mutant for genes associated with schizophrenia: common phenotype or distinct endophenotypes? Behav Brain Res 2009; 204: 258-273.

26 Boksa P. Effects of prenatal infection on brain development and behavior: a review of findings from animal models. Brain Behav Immun 2010; 24: 881-897.

27 Rana SA, Aavani T, Pittman QJ. Sex effects on neurodevelopmental outcomes of innate immune activation during prenatal and neonatal life. Horm Behav 2012; 62 : 228-236.

28 Ochoa S, Usall J, Cobo J, Labad X, Kulkarni J. Gender differences in schizophrenia and first-episode psychosis: a comprehensive literature review. Schizophr Res Treatment 2012; 2012: 916198.

29 Ohuchi H, Hamada A, Matsuda H, Takagi A, Tanaka M, Aoki J et al. Expression patterns of the lysophospholipid receptor genes during mouse early development. Dev Dyn 2008; 237: 3280-3294.

30 Ohta H, Sato K, Murata N, Damirin A, Malchinkhuu E, Kon J et al. Ki16425, a subtype-selective antagonist for EDG-family lysophosphatidic acid receptors. Mol Pharmacol 2003; 64: 994-1005.

31 Santin LJ, Bilbao A, Pedraza C, Matas-Rico E, López-Barroso D, Castilla-Ortega E et al. Behavioral phenotype of maLPA1-null mice: increased anxiety-like behavior and spatial memory deficits. Genes Brain Behav 2009; 8: 772-784.

32 Harrison SM, Reavill C, Brown G, Brown JT, Cluderay JE, Crook B et al. LPA1 receptor-deficient mice have phenotypic changes observed in psychiatric disease. Mol Cell Neurosci 2003; 24: 1170-1179.

33 Castilla-Ortega E, Sánchez-López J, Hoyo-Becerra C, Matas-Rico E, ZambranaInfantes $E$, Chun J et al. Exploratory, anxiety and spatial memory impairments are dissociated in mice lacking the LPA1 receptor. Neurobiol Learn Mem 2010; 94 73-82.

34 Graler MH, Goetzl EJ. The immunosuppressant FTY720 down-regulates sphingosine 1-phosphate G-protein-coupled receptors. FASEB J 2004; 18: 551-553.

35 Oo ML, Chang SH, Thangada S, Wu MT, Rezaul K, Blaho V et al. Engagement of S1P (1)-degradative mechanisms leads to vascular leak in mice. J Clin Invest 2011; 121 $2290-2300$

36 Choi JW, Gardell SE, Herr DR, Rivera R, Lee CW, Noguchi K et al. FTY720 (fingolimod) efficacy in an animal model of multiple sclerosis requires astrocyte sphingosine 1-phosphate receptor 1 (S1P1) modulation. Proc Natl Acad Sci USA 2011 108: $751-756$.

37 Oo ML, Thangada S, Wu MT, Liu CH, Macdonald TL, Lynch KR et al. Immunosuppressive and anti-angiogenic sphingosine 1-phosphate receptor-1 agonists induce ubiquitinylation and proteasomal degradation of the receptor. J Biol Chem 2007; 282: 9082-9089.

38 Reif A, Schmitt A, Fritzen S, Lesch KP. Neurogenesis and schizophrenia: dividing neurons in a divided mind? Eur Arch Psychiatry Clin Neurosci 2007; 257: 290-299.

39 Allen N, Bagade S, McQueen MB, loannidis JP, Kavvoura FK, Khoury MJ et al. Systematic meta-analyses and field synopsis of genetic association studies in schizophrenia: the SzGene database. Nat Genet 2008; 4: 827-834.

40 Jia P, Sun J, Guo A. Y, Zhao Z. SZGR: a comprehensive schizophrenia gene resource. Mol Psychiatry 2010; 15: 453-462.

41 Higgs B, Elashoff M, Richman S, Barci B. An online database for brain disease research. BMC Genomics 2006; 7: 70.

42 Yanagi M, Southcott S, Lister J, Tamminga C. Animal models of schizophrenia emphasizing construct validity. Prog Mol Biol Trans/ Sci 2012; 105: 411-444.

43 Herr KJ, Herr DR, Lee CW, Noguchi K, Chun J. Stereotyped fetal brain disorganization is induced by hypoxia and requires lysophosphatidic acid receptor 1 (LPA1) signaling. Proc Natl Acad Sci USA 2011; 108: 15444-15449.

44 Gaisler-Salomon I, Miller GM, Chuhma N, Lee S, Zhang H, Ghoddoussi F et al. Glutaminase-deficient mice display hippocampal hypoactivity, insensitivity to propsychotic drugs and potentiated latent inhibition: relevance to schizophrenia. Neuropsychopharmacology 2009; 34: 2305-2322.

45 Revel FG, Meyer CA, Bradaia A, Jeanneau K, Calcagno E, André CB et al. Brain-specific overexpression of trace amine-associated receptor 1 alters monoaminergic neurotransmission and decreases sensitivity to amphetamine. Neuropsychopharmacology 2012; 37: 2580-2592.

46 Ramsey JM, Schwarz E, Guest PC, van Beveren NJ, Leweke FM, Rothermundt M et al. Distinct molecular phenotypes in male and female schizophrenia patients PLoS One 2013; 8: e78729.

47 Cutolo M, Seriolo B, Villaggio B, Pizzorni C, Craviotto C, Sulli A. Androgens and estrogens modulate the immune and inflammatory responses in rheumatoid arthritis. Ann N Y Acad Sci 2002; 966: 131-142.

48 McCombe PA, Greer JM, Mackay IR. Sexual dimorphism in autoimmune disease. Curr Mol Med 2009; 9: 1058-1079.

49 Graler MH, Goetzl EJ. Lysophospholipids and their G protein-coupled receptors in inflammation and immunity. Biochim Biophys Acta 2002; 1582: 168-174.
50 Cruz-Orengo L, Daniels BP, Dorsey D, Basak SA, Grajales-Reyes JG, McCandless EE et al. Enhanced sphingosine-1-phosphate receptor 2 expression underlies female CNS autoimmunity susceptibility. J Clin Invest 2014; 124: 2571-2584.

51 Garcia-Fernandez M, Castilla-Ortega E, Pedraza C, Blanco E, Hurtado-Guerrero I, Barbancho MA et al. Chronic immobilization in the malpar1 knockout mice increases oxidative stress in the hippocampus. Int J Neurosci 2012; 122: 583-589.

52 Pedraza C, Sánchez-López J, Castilla-Ortega E, Rosell-Valle C, Zambrana-Infantes E, García-Fernández $\mathrm{M}$ et al. Fear extinction and acute stress reactivity reveal a role of LPA1 receptor in regulating emotional-like behaviors. Brain Struct Funct 2013; 219: 1659-1672.

53 Santin LJ, Bilbao A, Pedraza C, Matas-Rico E, López-Barroso D, Castilla-Ortega E et al. Behavioral phenotype of maLPA1-null mice: increased anxiety-like behavior and spatial memory deficits. Genes Brain Behav 2009; 8: 772-784.

54 Levelt CN, Hubener M. Critical-period plasticity in the visual cortex. Annu Rev Neurosci 2012; 35: 309-330.

55 Kihara Y, Maceyka M, Spiegel S, Chun J. Lysophospholipid receptor nomenclature review: IUPHAR Review 8. Br J Pharmacol 2014; 171: 3575-3594.

56 Kihara Y, Mizuno H, Chun J. Lysophospholipid receptors in drug discovery. Exp Cell Res 2014; 14: in press.

57 Chun J, Brinkmann V. A mechanistically novel, first oral therapy for multiple sclerosis: the development of fingolimod (FTY720, Gilenya). Discov Med 2011; 12: 213-228.

58 Cohen JA, Chun J. Mechanisms of fingolimod's efficacy and adverse effects in multiple sclerosis. Ann Neurol 2011; 69: 759-777.

59 Lisman JE, Coyle JT, Green RW, Javitt DC, Benes FM, Heckers S et al. Circuit-based framework for understanding neurotransmitter and risk gene interactions in schizophrenia. Trends Neurosci 2008; 31: 234-242.

60 McNally JM, McCarley RW, Brown RE. Impaired GABAergic neurotransmission in schizophrenia underlies impairments in cortical gamma band oscillations. Curr Psychiatry Rep 2013; 15: 346.

61 Lin C-H, Lane H-Y, Tsai GE. Glutamate signaling in the pathophysiology and therapy of schizophrenia. Pharmacol Biochem Behav 2012; 100: 665-677.

62 Shano S, Moriyama R, Chun J, Fukushima N. Lysophosphatidic acid stimulates astrocyte proliferation through LPA1. Neurochem Int 2008; 52: 216-220.

63 Pilpel Y, Segal M. The role of LPA1 in formation of synapses among cultured hippocampal neurons. J Neurochem 2006; 97: 1379-1392.

64 Cunningham MO, Hunt J, Middleton S, LeBeau FE, Gillies MJ, Davies CH et al. Regionspecific reduction in entorhinal gamma oscillations and parvalbumin-immunoreactive neurons in animal models of psychiatric illness. J Neurosci 2006; 26: 2767-2776.

65 Trimbuch T, Beed P, Vogt J, Schuchmann S, Maier N, Kintscher M et al. Synaptic PRG-1 modulates excitatory transmission via lipid phosphate-mediated signaling. Cell 2009; 138: 1222-1235.

66 Yang M, Zhong WW, Srivastava N, Slavin A, Yang J, Hoey T et al. G protein-coupled lysophosphatidic acid receptors stimulate proliferation of colon cancer cells through the \{beta\}-catenin pathway. Proc Natl Acad Sci USA 2005; 102: 6027-6032.

67 Sun Y, Kim N-H, Yang H, Kim S-H, Huh S-O. Lysophosphatidic acid induces neurite retraction in differentiated neuroblastoma cells via GSK-3 $\beta$ activation. Mol Cells 2011; 31: 483-489.

68 Mao Y, Ge X, Frank CL, Madison JM, Koehler AN, Doud MK et al. Disrupted in schizophrenia 1 regulates neuronal progenitor proliferation via modulation of GSK3b/b-catenin signaling. Cell 2009; 136: 1017-1031.

69 Lovestone S, Killick R, Di Forti M, Murray R. Schizophrenia as a GSK-3 dysregulation disorder. Trends Neurosci 2007; 30: 142-149.

70 Patterson PH. Immune involvement in schizophrenia and autism: etiology, pathology and animal models. Behav Brain Res 2009; 204: 313-321.

71 Gardner MR. Outcomes in children experiencing neurologic insults as preterm neonates. Pediatr Nurs 2005; 31: 448, 451-446.

72 Kinney DK, Yurgelun-Todd DA, Tohen M, Tramer S. Pre- and perinatal complications and risk for bipolar disorder: a retrospective study. J Affect Disord 1998; 50: 117-124.

73 Preti A, Cardascia L, Zen T, Pellizzari P, Marchetti M, Favaretto G et al. Obstetric complications in patients with depression-a population-based casecontrol study. J Affect Disord 2000; 61: 101-106.

74 Gardener H, Spiegelman D, Buka SL. Prenatal risk factors for autism: comprehensive meta-analysis. Br J Psychiatry 2009; 195: 7-14.

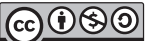

This work is licensed under a Creative Commons AttributionNonCommercial-ShareAlike 4.0 International License. The images or other third party material in this article are included in the article's Creative Commons license, unless indicated otherwise in the credit line; if the material is not included under the Creative Commons license, users will need to obtain permission from the license holder to reproduce the material. To view a copy of this license, visit http:// creativecommons.org/licenses/by-nc-sa/4.0/ 